\title{
Toward Production of a Vaccine for Addiction
}

\author{
Hamidreza Famitafreshi ${ }^{1}$ and Morteza Karimian ${ }^{2 *}$ \\ ${ }^{1}$ Physiology Department, Tehran University of Medical Sciences, International campus, Tehran, Iran \\ ${ }^{2}$ Physiology Department, Tehran University of Medical Sciences, Tehran, Iran
}

*Corresponding author: MortezaKarimian,Physiology Department, Tehran University of Medical Sciences, Tehran, Iran.

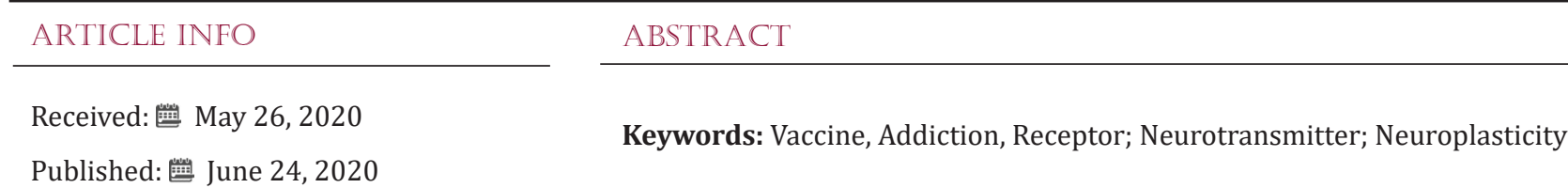

Citation: Hamidreza F, Morteza K. Toward Production of a Vaccine for Addiction. Biomed J Sci \& Tech Res 28(3)-2020. BJSTR. MS.ID.004657.

\section{Editorial}

Production of vaccines for many diseases is potentially the desired opinion. However, this desire elicited also potentially some questions and unambiguity. Generally, for vaccine production a specific protein should be targeted [1]. The nature of this protein can be an overproduced neurotransmitter or receptor [2]. It is reasonable to think by production of antibodies against unwanted neurotransmitters and receptors the addiction brings into control somehow.

Based on studies about addiction, addiction is a multistage disease that a critical step should be targeted [3]. This critical step can be considered the critical time in the emergence of dangerous addiction that is defined as emergence of compulsive drug seeking and taking behavior and reward center insufficiency play an important role [4]. It has been well documented that immune system around reward center is very sensitive to drug abuse and cannot function well in this area [5]. This encourages the concept of keeping balance of the immune system around this area. On the other hand, immune system over activation also is a harmful event that destroys normal brain neurons.

So, for production of a vaccine for addiction two ways should be considered:

a) Strengthening the immune system and

b) Weakening of the immune system
Toll-like immune cells in this regard play an important role because innate immune system is mostly affected as the result of drug abuse [6]. Also, these cells control many different cytokines release and also many different immune cell functions in brain. New studies show these cells can be targeted for keeping the normal transmitter release in reward center. Other reasons for this decision are the fact that addiction is a multistage disease and from this prospect different pathways should be considered and one pathway that influences different stages is better [7]. A recent study well documented that toll-like receptor manipulation influences addictive behavior [8]. In this regard special attention to this cell type is of great importance for controlling of addiction.

\section{Conflict of Interests}

None to declare.

\section{References}

1. Pashine A, Valiante NM, Ulmer JB (2005) Targeting the innate immune response with improved vaccine adjuvants. Nature medicine 11: S63.

2. Tanaka S, Matsunaga H, Kimura M, Tatsumi KI, Hidaka Y, et al. (2003) Autoantibodies against four kinds of neurotransmitter receptors in psychiatric disorders. Journal of neuroimmunology 141: 155-164.

3. Koob GF, Volkow ND (2016) Neurobiology of addiction: a neurocircuitry analysis. The Lancet Psychiatry 3: 760-773.

4. Le Moal M (2009) Drug abuse: vulnerability and transition to addiction. Pharmacopsychiatry 42: S42-S55.

5. Crews FT (2012) Immune function genes, genetics, and the neurobiology of addiction. Alcohol research: current reviews 34: 355. 
6. Guerri C, Pascual M (2019) Impact of neuroimmune activation induced by alcohol or drug abuse on adolescent brain development. International Journal of Developmental Neuroscience 77: 89-98.

7. Crews FT,Walter TJ, Coleman LG, VetrenoRP (2017) Toll-like receptor signaling and stages of addiction. Psychopharmacology 234: 1483-1498.

ISSN: 2574-1241

DOI: $10.26717 /$ BJSTR.2020.28.004657

Morteza Karimian. Biomed J Sci \& Tech Res

This work is licensed under Creative Commons Attribution 4.0 License

Submission Link: https://biomedres.us/submit-manuscript.php
8. Zhu $\mathrm{R}, \mathrm{Bu} \mathrm{Q}, \mathrm{Fu} \mathrm{D}$, Shao $\mathrm{X}$, Jiang $\mathrm{L}$, et al. (2018) Toll-like receptor 3 modulates the behavioral effects of cocaine in mice. Journal of neuroinflammation 15: 93.

$\begin{array}{ll}\text { BIOMEDICAL } & \text { Assets of Publishing with us } \\ \text { RESEARCHES } & \text { - Global archiving of articles } \\ \text { - Immediate, unrestricted online access }\end{array}$

